\title{
PENDEKATAN KONSELING SPIRITUAL PADA LANJUT USIA (LANSIA)
}

\author{
Oleh: Dra. St. Rahmah, M.Ag
}

\begin{abstract}
Later years and growing old is a natural process that is experienced by bumans, slowly but surely going to happen and have a direct impact on the various aspects of life. Facts show various problems can occur because of unpreparedness of the elderly in accepting all the changes that happened.

Supposedly the elderly should be able to complete the development tasks optimally and ultimately having personal integrity fully in receiving physical decline, and social well psikbis. The readiness of the elderly in receiving various reduction in the physical, psychological and social well can help achieve multidimensional bealth in living the rest of life in old age.

Spiritual counseling approach with various techniques such as prayer, teaching the concepts of spiritual, scriptural references, spiritual experiences, spiritual confrontation, prayers shared between the client and the counselor, the urge to forgive, the use of community or religious groups, prayer client, religious bibliotherapy. Spiritual counseling approach is very appropriate for the elderly so that old age life more meaningful and they can fill their lives with things that are productive and useful.
\end{abstract}

Keyword: Spiritual Counseling, Elderly

\section{A. PENDAHULUAN}

Masa tua adalah masa paling akhir dari siklus kehidupan manusia, pada masa-masa ini akan terjadi proses penuaan atau aging yang merupakan suatu proses yang dinamis sebagai akibat dari perubahan-perubahan sel, fisioligis dan psikologis. Pada masa ini manusia berpotensi mempunyai masalah-masalah kesehatan secara umum maupun kesehatan jiwa (Damayanti : 2008). Lansia (lanjut usia) bukan suatu penyakit tapi tahap lanjut dari proses kehidupan manusia, walaupun bukan penyakit tetapi kondisi ini dapat menimbulkan masalah fisik, sosial dan mental. Kaum lanjut usia sering dianggap tidak berdaya, sakit-sakitan, tidak produktif dan sebagainya. Tidak jarang mereka diperlakukan sebagai beban keluarga, masyarakat, hingga negara. Orang yang sudah lanjut usia seringkali mendapat perlakuan yang sebenarnya tidak mereka inginkan, misalnya selalu disuruh duduk saja. Apa yang orang muda lakukan pada mereka yang sudah lansia sebenarnya merupakan suatu kesalahan.

Lanjut usia adalah bagian dari tahap perkembangan dewasa akhir yang pasti akan dialami oleh manusia secara alamiah. $\mathrm{P}$ ada periode ini terjadi banyak penurunan baik fisik maupun psikologis yang akan berdampak dalam interaksi sosial. Penurunan kondisi fisik dan psikologis ini akan berkontribusi terhadap berbagai permasalahan yang dialami para lanjut usia.

Kondisi kesehatan fisik maupun psikologis semestinya tidak menghambat para lanjut usia dalam menuntaskan tugas-tugas perkembangannya secara optimal. Di usia senja hendaknya para lanjut usia juga mampu mencapai integritas kepribadian dalam penerimaan kondisi fisik maupun psikologis yang 
mulai menurun sehingga mencapai kesehatan yang multidimensional.

Untuk mewujudkan kondisi tersebut perlu ada upaya bersama dari berbagai pihak dalam memfasilitasi para lanjut usia dalam mengisi sisa kehidupannya dengan bahagia dan berkualitas secara fisik dan psikis. Diantara upaya yang dapat dilakukan adalah dengan memberikan layanan konseling spiritual pada para lanjut usia, karena konseling spiritual dipandang efektif untuk meningkatkan kesehatan multidimensional dan komprehensif para lanjut usia.

\section{B. MASALAH PADA LANJUT USIA}

Lanjut usia dalam ilmu psikologi yang dikenal dengan istilah lain seperti Old Age atau Elderly. Lanjut usia adalah istilah yang dipergunakan untuk menunjuk pada orang- orang yang sudah menjadi tua. Dalam Psikologi Perkembangan masa tua atau lanjut usia merupakan suatu harapan terakhir dari rentang kehidupan manusia yang secara teoritis dimulai ketika seseorang memasuki usia 60 tahun sampai dengan meninggal. (Hurlock, E. B.; 1992; 122)

Lanjut usia adalah tahap dimana terjadi penuaan dan penurunan, yang penurunannya lebih jelas dan lebih dapat diperhatikan daripada tahap usia bayi. Penuaan merupakan perubahan kumulatif pada makhluk hidup. Pada manusia, penuaan dihubungkan dengan perubahan degenerative pada kulit, tulang, jantung, pembuluh darah, paru-paru, saraf dan jaringan tubuh lainnya. Dengan kemampuan yang terbatas, mereka lebih rentan terhadap berbagai penyakit, sindroma dan kesakitan dibandingkan dengan dewasa lainnya (Hasan: 2006).

Lansia (lanjut usia) merupakan seseorang yang karena usianya mengalami perubahan biologis, fisis, kejiwaan dan sosial (UU No23 Tahun 1992 tentang kesehatan). Pengertian dan pengelolaan lansia menurut Undang -Undang Republik Indonesia Nomor 13 Tahun 1998 tentang lansia sebagai berikut :

a. Lanjut usia adalah seseorang yang telah mencapai usia 60 tahun keatas

b. Lanjut usia potensial adalah lansia yang masih mampu melakukan pekerjaan

c. dan kegiatan yang dapat menghasilkan barang atau jasa

d. Lanjut usia tak potensial adalah lanjut usia yang tidak berdaya mencari nafkah sehinggahidupnya tergantung pada bantuan orang lain.

Menurut Organisasi Kesehatan Dunia, lanjut usia meliputi: usia pertengahan yakni; kelompok usia 46-59 tahun, usia lanjut (Elderly) yakni antara usia 60 -74 tahun, Tua (Old) yaitu antara 75- 90 tahun, dan usia sangat tua (Very old) yaitu usia diatas 90 tahun (Setiabudhi, 1999), sedangkan menurut DepKes RI tahun 1999, umur lanjut usia terbagi 3 yaitu;

a. Usia pra senelis atau Virilitas adalah seseorang yang berusia 45-49 tahun 
b. Usia lanjut adalah seseorang yang berusia 60 tahun atau lebih

c. Usia lanjut resiko tinggi adalah seseorang yang berusia 70 tahun atau lebih atau dengan masalah kesehatan.

Menurut Constantindes (1994)

dalam Nugroho (2000) mengatakan bahwa proses menua adalah suatu proses menghilangnya secara perlahan-lahan kemampuan jaringan untuk memperbaiki diri atau mengganti dan mempertahankan fungsi normalnya, sehingga tidak dapat bertahan terhadap infeksi dan memperbaikinya terhadap kerusakan yang diderita. Proses menua merupakan proses yang terus-menerus secara alamiah dimulai sejak lahir dan setiap individu tidak sama cepatnya. Menua bukan status penyakit tetapi merupakan proses berkurangnya daya tahan tubuh dalam menghadapi rangsangan dari dalam maupun dari luar tubuh.

Dengan begitu manusia secara progresif akan kehilangan daya tahan terhadap infeksi dan akan menumpuk makin banyak distorsi metabolik dan stuktural yang disebut sebagai penyakit degeneratif seperti, hipertensi, aterosklerosis, diabetes militus dan kanker yang akan menyebabkan kita menghadapi akhir hidup dengan episode terminal yang dramatic seperti strok, infark miokard, koma asidosis, metastasis kanker dan sebagainya (Darmojo, 2004)

Suatu proses yang tidak dapat dihindari yang berlangsung secara terusmenerus dan berkesinambungan yang selanjutnya menyebabkan perubahan anatomis, fisiologis dan biokemis. pada jaringan tubuh dan akhirnya mempengaruhi fungsi dan kemampuan badan secara keseluruhan (Depkes RI, 1998). Menurut Setiabudhi (1999) akan terjadi perubahan pada lanjut usia yaitu, perubahan dari aspek biologis, perubahan Fisiologis, perubahan Psikologis perubahan sosial, dan perubahan pada kehidupan keluarga. Perubahan-

perubahan tersebut pada umumnya mengarah pada kemunduruan kesehatan fisik dan psikis yang akhirnya akan berpengaruh dan menimbulkan masalah pada mereka, sehingga secara umum akan berpengaruh pada aktivitas kehidupan sehari-hari.

Secara umum, masalah yang sering terjadi pada lansia di bedakan menjadi masalah fisik dan fisiologis serta masalah psikologis. Masalah ini akan di jelaskan di bawah ini:

1. Permasalahan dari Aspek Fisiologis

Terjadinya perubahan normal pada fisik lanjut usia yang dipengaruhi oleh faktor kejiwaan sosial, ekonomi dan medik. Perubahan tersebut akan terlihat dalam jaringan dan organ tubuh seperti kulit menjadi kering dan keriput, rambut beruban dan rontok, penglihatan menurun sebagian atau menyeluruh, pendengaran berkurang, indra perasa menurun, daya penciuman berkurang, tinggi badan menyusut karena proses osteoporosis yang berakibat badan menjadi bungkuk, tulang keropos, massanya dan kekuatannya berkurang dan mudah patah, elastisitas paru berkurang, nafas menjadi pendek, 
terjadi pengurangan fungsi organ didalam perut, dinding pembuluh darah menebal sehingga tekanan darah tinggi, otot jantung bekerja tidak efisien, adanya penurunan organ reproduksi terutama pada wanita, otak menyusut dan reaksi menjadi lambat terutama pada pria, serta seksualitas tidak terlalu menurun.

2. Permasalahan dari Aspek Psikologis

Menurut Hadi Martono (1997) dalam Darmojo (1999), beberapa masalah psikologis lanjut usia antara lain:

a. Kesepian (loneliness), yang dialami oleh lanjut usia pada saat meninggalnya pasangan hidup, terutama bila dirinya saat itu mengalami penurunan status kesehatan seperti menderita penyakit fisik berat, gangguan mobilitas atau gangguan sensorik terutama gangguan pendengaran harus dibedakan antara kesepian dengan hidup sendiri. Banyak lanjut usia hidup sendiri tidak mengalami kesepian karena aktivitas sosialnya tinggi, lansia yang hidup dilingkungan yang beranggota keluarga yang cukup banyak tetapi mengalami kesepian.

Pada umumnya masalah yang paling banyak terjadi pada lanjut usia adalah kesepian. Kesepian merupakan hal yang bersifat pribadi dan akan ditanggapi berbeda oleh setiap orang, bagi sebagian orang kesepian merupakan yang bisa diterima secara normal namun bagi sebagian orang kesepian bisa menjadi sebuah kesedihan yang mendalam. Kesepian terjadi saat klien mengalami terpisah dari orang lain dan mengalami gangguan sosial. Dalam banyak kasus kesepian menyebabkan kesehatan fisik dan mental mengalami penekanan karena mereka tidak mempunyai teman berbelanja dan makan bersama.

Kesepian pada lanjut usia dipandang unik karena akibatnya akan berdampak pada gangguan kesehatan yang kompleks. Lebih jauh dikatakan bahwa perasaan kesepian terdapat dua jenis yaitu kesepian emosional dan kesepian sosial. Dalam kesepian emosional, seseorang merasa tidak memiliki kedekatan dan perhatian dalam berhubungan sosial, merasa tidak ada satu orang pun yang peduli terhadapnya, sedangkan kesepian sosial muncul dari kurangnya jaringan sosial dan ikatan komunikasi atau dapat dijelaskan sebagai suatu respon dari tidak adanya ikatan dalam suatu jaringan sosial.

b. Duka cita (bereavement), pada periode duka cita ini merupakan periode yang sangat rawan bagi lanjut usia. meninggalnya pasangan hidup, teman dekat, atau bahkan hewan kesayangan bisa meruntuhkan ketahanan kejiwaan yang sudah rapuh dari seorang lanjut usia, yang selanjutnya memicu terjadinya gangguan fisik dan kesehatannya. 
Adanya perasaan kosong kemudian diikuti dengan ingin menangis dan kemudian suatu periode depresi. Depresi akibat duka cita biasanya bersifat self limiting.

c. Depresi, persoalan hidup yang mendera lanjut usia seperti kemiskinan, usia, stress yang berkepanjangan, penyakit fisik yang tidak kunjung sembuh, perceraian atau kematian pasangan, keturunan yang tidak bisa merawatnya dan sebagainya dapat menyebabkan terjadinya depresi. Gejala depresi pada usia lanjut sedikit berbeda dengan dewasa muda, dimana pada usia lanjut terdapat gejala somatik. Pada usia lanjut rentan untuk terjadi: episode depresi berat dengan ciri melankolik, harga diri rendah, penyalahan diri sendiri, ide bunuh diri, penyebab terjadinya depresi merupakan gabungan antara faktor-faktor psikologik, sosial dan biologik. Seorang usia lanjut yang mengalami depresi bisa saja mengeluhkan mood yang menurun, namun kebanyakan menyangkal adanya depresi. Yang sering terlihat adalah hilangnya tenaga/energi, hilangnya rasa senang, tidak bisa tidur atau keluhan rasa sakit dan nyeri kecemasan dan perlambatan motorik, (Stanley\&Beare, 2002).

d. Gangguan cemas, terbagi dalam beberapa golongan yaitu fobia, gangguan panik, gangguan cemas umum, gangguan stress setelah trauma dan gangguan obstetif- kompulsif. Pada lanjut usia gangguan cemas merupakan kelanjutan dari dewasa muda dan biasanya berhubungan dengan sekunder akibat penyakit medis, depresi, efek samping obat atau gejala penghentian mendadak suatu obat.

Kecemasan yang tersering pada usia lanjut adalah tentang kematiannya. Orang mungkin menghadapi pikiran kematian dengan rasa putus asa dan kecemasan, bukan dengan ketenangan hati dan rasa integritas. Kerapuhan sistem saraf anotomik yang berperan dalam perkembangan kecemasan setelah suatu stressor yang berat. Usia lanjut dipandang sebagai masa degenerasi biologis yang disertai oleh penderitaan berbagai dengan masa penyakit dan keudzuran serta kesadaran bahwa setiap orang akan mati, maka kecemasan akan kematian menjadi masalah psikologis yang penting pada lanjut usia, khususnya lanjut usia yang mengalami penyakit kronis. Pada orang lanjut usia biasanya memiliki kecenderungan penyakit kronis (menahun/berlangsung beberapa tahun) dan progresif (makin berat) sampai penderitanya mengalami kematian.

e. Psikosis pada lanjut usia, dimana terbagi dalam bentuk psikosis bisa terjadi pada lanjut usia, baik sebagai kelanjutan keadaan dari dewasa 
muda atau yang timbul pada lanjut usia.

f. Parafrenia, merupakan suatu bentuk skizofrenia lanjut yang sering terdapat pada lanjut usia yang ditandai dengan waham (curiga) yang sering lansia merasa tetangganya mencuri barangbarangnya atau tetangga berniat membunuhnya. Parafrenia biasanya terjadi pada lanjut usia yang terisolasi atau diisolasi atau menarik diri dari kegiatan sosial.

g. Sindroma diagnose, merupakan suatu keadaan dimana lanjut usia menunjukkan penampilan perilaku yang sangat mengganggu. Rumah atau kamar yang kotor serta berbau karena lansia ini sering bermainmain dengan urin dan fesesnya. Lanjut usia sering menumpuk barang-barangnya dengan tidak teratur.

\section{PENDEKATAN KONSELING SPIRITUAL PADA LANJUT USIA}

Konseling adalah terjemahan dan kata counseling, mempunyai makna sebagai hubungan timbal balik antara dua orang individu, dimana yang seorang (konselor) berusaha membantu yang lain (klien) untuk mencapai pengertian tentang dirinya sendiri dalam hubungan dengan masalah-masalah yang dihadapinya pada waktu yang akan datang (Natawijaya, 1987). Sedangkan menurut Surya (1988), pengertian konseling adalah seluruh upaya bantuan yang diberikan konselor kepada konseli supaya dia memperoleh konsep diri dan kepercayaan diri sendiri, untuk dimanfaatkan olehnya dalam memperbaiki tingkah lakunya pada masa yang akan datang. Dalam pembentukan konsep kepribadian yang sewajarnya mengenai : dirinya sendiri, orang lain, pendapat orang lain tentang dirinya, tujuan-tujuan yang hendak dicapai, dan kepercayaan diri.

Spiritual berhubungan dengan aspek kepercayaan manusia terhadap kekuasaan Sang Pencipta, meyakini wujud ciptaanNya berupa alam semesta beserta isinya. Seperti halnya dengan keyakinan dalam agama maka spiritual dan agama tidak dapat dipisahkan karena keduanya mempengaruhi kehidupan manusia. Spiritual yang dalam bahasa Latin berarti k ekuatan hidup berkontribusi positif pada ke mampuan diri untuk menghidupkan kekuatan hidup pada manusia.

Spiritual adalah kebutuhan dasar dan pencapaian tertinggi seorang manusia dalam kehidupannya tanpa memandang suku atau asal-usul. Kebutuhan dasar tersebut meliputi: kebutuhan fisiologis, keamanan dan keselamatan, cinta kasih, dihargai dan aktualitas diri. Aktualitas diri merupakan sebuah tahapan Spiritual seseorang, dimana berlimpah dengan kreativitas, intuisi, keceriaan, sukacita, kasih sayang, kedamaian, toleransi, kerendahatian serta memiliki tujuan hidup yang jelas (Maslow 1970, dikutip dari Prijosaksono, 2003).

Spiritual merupakan keyakinan dalam hubungannya dengan Yang Maha Kuasa dan Maha Pencipta (Hamid, 
1999). Spiritual juga disebut sebagai sesuatu yang dirasakan tentang diri sendiri dan hubungan dengan orang lain, yang dapat diwujudkan dengan sikap mengasihi orang lain, baik dan ramah terhadap orang lain, menghormati setiap orang untuk membuat perasaan senang seseorang. Spiritual adalah kehidupan, tidak hanya doa, mengenal dan mengakui Tuhan (Nelson, 2002).

Konseling spiritual adalah sebuah proses pemberian bantuan kepada individu agar memiliki kemampuan untuk mengembangkan fitrahnya sebagai makhluk beragama (homo religious), berperilaku sesuai dengan nilai-nilai agama (berakhlak mulia), dan mengatasi masalah-masalah kehidupan melalui pemahaman, keyakinan, dan praktik-praktik ibadah ritual agama yang dianutnya".(SyamsuYusuf L.N; 2009; 6)

Dengan demikian konseling spiritual merupakan sebuah terapi kejiwaan melalui pendekatan agama, dalam agama Islam konseling spiritual berpedoman pada ajaran Islam, diantaranya dalam Al Qur'an surah Yunus ayat 57 :

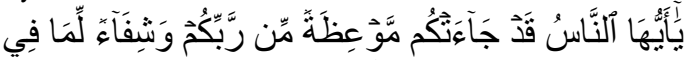

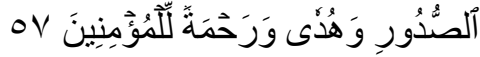

Artinya: 'Hai manusia, sesunggubnya telah datang kepadamu pelajaran dari Tubanmu dan penyembub bagi penyakit-penyakit (yang berada) dalam dada dan petunjuk serta rahmat bagi orang-orang yang beriman'.
Pengintegrasian nilai-nilai agama dengan konseling merupakan upaya yang sangat berarti untuk pengembangan profesi konseling yang lebih komprehensif, yakni tidak hanya sebatas mengembangkan atau menyelesaikan masalah pola pikir, emosi, sikap, atau tingkah laku klien, tetapi meliputi perkembangan kepribadiannya secara utuh sebagai makhluk yang berdimensi biospikososiospiritual.

Ketika nilai-nilai agama (spiritual) ini diintegrasikan dengan konseling maka suasana kebahagiaan dan ketenangan itu akan hadir dengan sendirinya. Hal ini terjadi karena dalam diri setiap manusia terdapat fitrah, fitrah untuk selalu mengakui akan keberadaan Tuhan. Kondisi ini muncul karena berlandaskan pada nilai-nilai spiritual. Landasan nilai-nilai religi yang kuat pada dasarnya merupakan suasana yang kondusif bagi terciptanya kehidupan. Suasana seperti itu akan menumbuhkan kualitas manusia agamis yang memiliki ketahanan dan keberdayaan yang lebih baik.

Konseling spiritual berlandaskan kepada pandangan tentang Tuhan, hakekat manusia, tujuan hidup, spiritualitas, moralitas, dan hidup setelah mati.

1. Pandangan tentang Tuhan

Seorang muslim meyakini Allah sebagai Tuhan yang menciptakan manusia dan alam semesta, Allah Maha Kasih Sayang, Kuasa, Maha Mengetahui, Maha Mendengar, dan Kekal. Allah telah menurunkan 
wahyu-Nya kepada nabi Muhammad, yang berupa kitab suci Al-qur'an.

2. Pandangan tentang hakikat manusia

Di dalam memahami hakekat manusia menurut perspektif Islam, haruslah dilihat dari sumber utama ajaran islam yaitu Al-Qur'an. Dalam Al-Qur'an diuraikan bagaimana Allah telah menciptakan manusia dari materi dan roh, melewati beberapa fase penciptaan sebagaimana Allah berfirman.

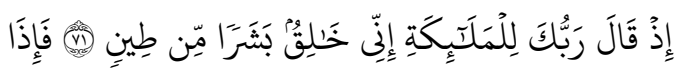

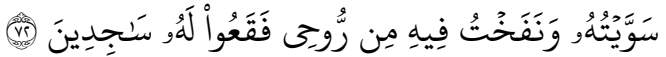
Artinya: Dan (ingatlah), ketika Tubanmu berfirman kepada para malaikat, „sesunggubnya Aku akan menciptakan manusia dari tanah liat kering (yang berasal) dari lumpur hitam yang diberi bentuk, maka apabila Aku telah menyempurnakan kejadiannya, dan telah kutiupkan ke dalamnya rob (ciptaan) Ku, maka tundukkanlah kamu kepadanya dengan bersujud'.( Q.S Shad (38): 71-72)

3. Pandangan tentang tujuan hidup

Tujuan hidup seorang muslim adalah memperoleh ridho Allah, untuk memperolehnya seorang muslim harus melakukan tugas dan kewajibannya hidup di dunia ini, yaitu beribadah kepada Allah, melalui habluminallah dan habluminannas.

4. Pandangan tentang spiritualitas

Ketaatan terhadap hukumhukum Allah yang tertulis dalam kitab suci Al-Qur'an telah mengembangkan spiritualitas setiap muslim. Spiritualitas yang dimiliki seorang muslim dapat mencegah dirinya dari perbuatan tercela seperti arogensi, tamak, dan tidak jujur, nilai spiritualitas seorang muslim diperoleh melalui pengalaman ibadah mahdlah, yaitu berkomunikasi langsung dengan Allah, seperti sholat, berdoa atau berdzikir, serta malafalkan kalimah toyyibah.

5. Pandangan Tentang Moralitas

Allah telah menurunkan hukumhukumnya dalam ALQur'an. Orang yang baik adalah yang menaati hukum-hukum, dan beribadah kepadaNya. Ada lima klasifikasi tindakan moral, yaitu wajib, sunnah, makruh, haram, dan mubah. Contoh tindakan moral yang buruk atau yang diharamkan adalah minumminuman keras, berjudi, dan berzina. Sementara contoh tindakan moral yang baik atau yang diwajibkan adalah seperti sholat, puasa, dan zakat. 6. Pandangan tentang hari akhir (akhirat)

Salah satu rukun iman dan islam adalah beriman kepada hari akhir. Hari akhir adalah hari pengadilan, pertanggungjawaban setiap perbuatan di dunia. Orang yang beramal baik akan dibalas dengan syurga dan yang beramal buruk akan dibalas dengan neraka.

Secara umum konseling spiritual atau keagamaan dilakukan dengan tujuan untuk memfasilitasi dan meningkatkan kemampuan klien untuk mengembangkan kesadaran beragama 
atau spiritualitasnya dan mengatasi masalah-masalah yang dihadapinya, sehingga dapat mencapai kehidupan yang bermakna. Kesadaran beragama atau spiritualitas klien yang baik diyakini akan berpengaruh secara positif dan fungsional terhadap aspek-aspek kehidupan pribadi lainnya.

Sedangkan secara khusus khusus konseling spiritual bertujuan sebagai berikut:

1. Pengalaman dan pemantapan identitas spiritual atau keyakinannya kepada Tuhan.

2. Memperoleh bimbingan dan kekuatan dari Tuhan dalam mengatasi masalah dan mengembangkan dirinya.

3. Memperoleh dukungan sosial dan emosional, sehinggga memiliki kekuatan untuk mengatasi masalah.

4. Menguji dan memperbaiki keyakinan dan praktik-praktik spiritualnya yang tidak berfungsi dangan baik (disfungsional).

5. Menerima tanggung jawab dan memperbaiki kekeliruan sikap dan perilakunya yang mementingkan diri sendiri (selfish).

6. Mengembangkan dirinya dalam kebenaran dan komitmen terhadap keyakinan, nilai-nilai keyakinan atau spiritualitasnya.

7. Mengaktualisasikan nilai-nilai keyakinan atau spiritualitas keagamaan dalam membangun kehidupan bersama yang sejahtera.". (Syamsu Yusuf L.N; 2009; 40).

Berdasarkan tujuan konseling spiritual tersebut ,maka yang membedakan konseling spiritual dengan sekuler adalah keyakinan bahwa Tuhan mengintervensi

kehidupan manusia untuk menolongnya agar dapat mengatasi masalah, memelihara

kesehatan, dan melakukan perubahan kehidupan ke arah yang lebih baik. Dalaam

proses memberikan bantuan terhadap klien, konselor spiritual memberikan dorongan

kepada mereka agar lebih meyakini Tuhan karena keyakinan terhadap Tuhan dapat membantu klien mengatasi masalah yang dihadapinya. Konselor memberikan keyakinan terhadap klien bahwa perubahan terapeutik yang terjadi yaitu kesembuhan

dan perkembangan dirinya difasilitasi oleh keyakinan akan petunjuk dan cinta kasihNya (Yusuf, 2007:27).

Dengan demikian aktivitas konseling spiritual merupakan jenis keterampilan yang pada intinya mengajak, membimbing, dan mengarahkan klien kembali kepada fitrah, maka siapa saja yang akan mendalami profesi ini, dia harus memiliki keimanan, kemakrifatan, dan ketauhidan yang berkualitas. Karena sudah sangat jelas, bahwa profesi konseling adalah usaha sadar untuk memahami kondisi klien baik secara jasmani maupun secara rohani yang kemudian mengantarkan konseli untuk menemukan solusi. (Hamdani Bakran Adz-Dzaki ; 2008; 23) 
Richards dan Bergin (2007) dalam Yusuf (2007:31) mengemukakan tentang konseling spiritual dapat dilakukan dengan teknik doa, mengajarkan konsep-konsep spiritual, referensi kitab suci, pengalaman spiritual, konfrontasi spiritual, do'a bersama antara klien dan konselor, dorongan memaafkan, penggunaan komunitas atau kelompok beragama, do'a klien, biblioterapi keagamaan, sebagai berikut:

\begin{tabular}{|c|c|c|c|}
\hline NO & INTERVENSI & KETERANGAN & CONTOH \\
\hline$\overline{1}$ & Counselor Prayer & $\begin{array}{l}\text { Pembacaan do’a } \\
\text { bagi klien }\end{array}$ & $\begin{array}{l}\text { Konselor mendo'akan klien agar } \\
\text { dapat } \\
\text { pemahaman tentang } \\
\text { dirinya masalah } \\
\text { mengatasinya. }\end{array}$ \\
\hline 2 & $\begin{array}{l}\text { Pemberian Informasi } \\
\text { tentang konsep-konsep } \\
\text { spiritual (teaching spiritual } \\
\text { Concepts) }\end{array}$ & $\begin{array}{l}\text { Pemberian } \\
\text { informasi tentang } \\
\text { isu-isu teologis dan } \\
\text { konsep-konsep } \\
\text { spiritual }\end{array}$ & $\begin{array}{l}\text { Konselor memberika informasi } \\
\text { agar klien berkembang } \\
\text { kesadarannya tentang kebenaran, } \\
\text { sikap cita kasih, dan kedamaian } \\
\text { sebagai nilai-nilai yang } \\
\text { terkandung dalam kitab suci } \\
\text { dan membantu klien agar } \\
\text { memandang dirinya berharga, } \\
\text { sesuai dengan firman Tuhan } \\
\text { tentang martabat dirinya. }\end{array}$ \\
\hline 3 & $\begin{array}{l}\text { Merujuk kepada kitab } \\
\text { suci (Reference to } \\
\text { Scripture) }\end{array}$ & $\begin{array}{l}\text { Membaca kitab } \\
\text { suci untuk } \\
\text { memantapkan } \\
\text { keyakinan. }\end{array}$ & $\begin{array}{l}\text { Klien bersama konselor } \\
\text { menelaah ayatayat dalam kitab } \\
\text { suci yang relevan dengan masalah } \\
\text { yang dihadapinya, sehingga dapat } \\
\text { mengcounter perasaannya yang } \\
\text { tidak tepat (seperti sikap } \\
\text { perfectionist) }\end{array}$ \\
\hline 4 & $\begin{array}{l}\text { Pengungkapan spiritual } \\
\text { diri (Spiritual selfdiclosure) }\end{array}$ & $\begin{array}{l}\text { Konselor mengung } \\
\text { kapkan } \\
\text { pengalaman } \\
\text { spiritualnya sendiri } \\
\text { untuk mencoba } \\
\text { mem pengaruhi } \\
\text { klien }\end{array}$ & 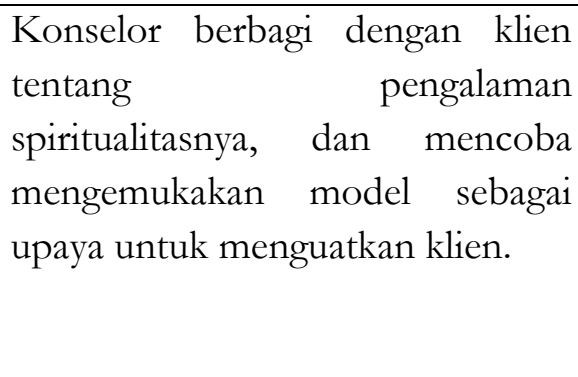 \\
\hline 5 & Konfrontasi Spiritual & Mengkronfontasi & Konselor mengkronfontasi klien \\
\hline
\end{tabular}




\begin{tabular}{|c|c|c|c|}
\hline & (Spiritual Confrontation) & $\begin{array}{l}\text { klien yang terkait } \\
\text { dengan keyakinan } \\
\text { spiritualnya }\end{array}$ & $\begin{array}{l}\text { mengenai ketidaksesuaian antara } \\
\text { nilai-nilai agama yang diyakininya } \\
\text { dengan perbuatannya. }\end{array}$ \\
\hline 6 & $\begin{array}{l}\text { Penilaian spiritual } \\
\text { (Spiritual Assesment) }\end{array}$ & $\begin{array}{l}\text { Konselor } \\
\text { menaksir status } \\
\text { spiritual atau } \\
\text { keberagamaan } \\
\text { klien }\end{array}$ & $\begin{array}{l}\text { Konselor } \\
\text { sejarah } \\
\text { perkembangan } \\
\text { klien, dan meneragamaan } \\
\text { perasaan } \\
\text { hubungannya klien dengan Tuhan, } \\
\text { melalui skala penilaian spiritual }\end{array}$ \\
\hline 7 & $\begin{array}{l}\text { Do'a bersama konselor } \\
\text { dengan klien (Counselor } \\
\text { and Client prayer) }\end{array}$ & $\begin{array}{l}\text { Do'a bersama klien } \\
\text { dalam pertemuan } \\
\text { konseling }\end{array}$ & $\begin{array}{l}\text { Konselor mengajak klien berdoa } \\
\text { pada } \\
\text { awal pertemuan } \\
\text { memperoleh petunjuk dan } \\
\text { pertolongannya baik selama } \\
\text { maupun setelh pertemuan }\end{array}$ \\
\hline 8 & $\begin{array}{lr}\text { Dorongan } & \text { untuk } \\
\text { memaafkan } & \\
\text { (Encouragement } & \text { For } \\
\text { Forgiveness) } & \end{array}$ & $\begin{array}{l}\text { Berdiskusi tentang } \\
\text { makna memaafkan } \\
\text { dan } \\
\text { mendorongnya } \\
\text { untuk memaafkan } \\
\text { orang lain }\end{array}$ & $\begin{array}{l}\text { Konselor mendiskusikan tentang } \\
\text { bagaimana makna memaafkan } \\
\text { baik terhadap diri sendiri (dari } \\
\text { rasa bersalah) maupun terhadap } \\
\text { orang lain dan bagaimana } \\
\text { menggunakan } \\
\text { memaafkan perbuatan } \\
\text { memperbaiki hubungan yang } \\
\text { retak. }\end{array}$ \\
\hline 9 & $\begin{array}{lr}\text { Penggunaan } & \text { komunitas } \\
\text { atau } & \\
\text { kelompok } & \text { beragama } \\
\text { (Use Of } & \text { Religious } \\
\text { Community) } & \end{array}$ & $\begin{array}{l}\text { Menggunakan } \\
\text { kelompok } \\
\text { beragama klien } \\
\text { sebagai sumber } \\
\text { terapi dari luar }\end{array}$ & $\begin{array}{l}\text { Konselor merujuk kepada } \\
\text { seorang ahli agama dari } \\
\text { kelompok beragama klien untuk } \\
\text { mendiskusikan masalah-masalah } \\
\text { teologis atau spiritual yang khusus }\end{array}$ \\
\hline 10 & Do'a klien (Client Prayer) & $\begin{array}{l}\text { Dorongan kepada } \\
\text { klien untuk berdo'a }\end{array}$ & $\begin{array}{l}\text { Konselor mendorong klien } \\
\text { untuk berdo'a memperoleh } \\
\text { petunjuk tentang bagaimana } \\
\text { memecahkan masalah yang } \\
\text { dihadapinya }\end{array}$ \\
\hline 11 & $\begin{array}{l}\text { Bibliotherapy } \\
\text { keagamaan } \\
\text { (Religious Bibliotherapy) }\end{array}$ & $\begin{array}{l}\text { Penggunaan } \\
\text { literatur } \\
\text { keagamaan }\end{array}$ & $\begin{array}{lll}\text { Konselor } & \text { mendorong } & \text { klien } \\
\text { untuk } & & \\
\text { membaca } & \text { buku-buku } & \text { atau }\end{array}$ \\
\hline
\end{tabular}


\begin{tabular}{|l|l|l|l|}
\hline & & & referensi keagamaan \\
\hline
\end{tabular}

Dengan berbagai teknik tersebut konseling spiritual dapat membantu konseli dalam meningkatkan kekuatan dan keyakinan yang $m$ enghubungkan dirinya dengan Tuhan dan alam semesta, sehingga terwujud perasaan tentram, damai, bahagia dan mencapai kesehatan di usia senja. Konselor dapat membantu konseli (lanjut usia) untuk menumbuhkan keyakinan bahwa setiap orang dalam hidupnya perlu menggapai kesehatan multidimensional. Proses konseling membantu konseli untuk lebih mengenal diri dan lingkungannya secara efektif sehingga muncul pemahaman yang lebih baik dan benar terhadap diri dan lingkungannya. Konseli juga dibantu secara bertahap untuk memperoleh kompetensi dalam mengenal dan mewujudkan harapan dalam kehidupan lanjut usia.

Sejalan dengan apa yang dikemukakan Lubis (2007:26) bahwa tujuan akhir dari konseling spiritual agar konseli terhindar dari berbagai masalah baik yang berkaitan dengan gejala neurose dan psychose, sosial dan spiritual, atau dengan kata lain agar masing-masing individu memiliki mental yang sehat.

Religiusitas atau penghayatan keagamaan tentu sangat besar pengaruhnya terhadap taraf kesehatan fisik dan mental lanjut usia, Berbagai penelitian yang telah dilakukan terhadap para lansia ternyata:
1) Lanjut usia yang non religious angka kematiannya dua kali lebih besar daripada religious

2) Lanjut usia yang religious penyembuhan penyakitnya lebih cepat daripada yang non religious

3) Lanjut usia yang religious lebih kebal dan lebih tenang dalam menghadapi operasi

4) Lanjut usia yang religious lebih kuat dan tabah menghadapi stress daripada yang kurang atau non religious, sehingga gangguan mental emosional jauh lebih kecil

5) 5. Lanjut usia yang religious tabah dan tenang menghadapi saat-saat terakhir (kematian) daripada yang kurang atau non religious. (Dadang Hawari; 1999; 293).

Karena itu nilai-nilai agama yang dianut oleh konseli merupakan satu hal yang perlu dipertimbangkan konselor dalam memberikan layanan konseling, terutama konseli yang fanatik dengan ajaran agamanya tentu sangat yakin dengan pemecahan masalah pribadinya melalui nilai-nilai ajaran agamanya. Sebagaimana yang dikemukakan oleh Bishop (1992:179) bahwa nilai-nilai agama (religius values) sangat penting untuk dipertimbangkan oleh konselor dalam proses konseling, agar proses konseling terlaksana secara efektif. Apalagi realitas yang terjadi di masyarakat pada zaman sekarang ini, bahwa banyak sekali orang- 
orang yang datang ketempat para kiai/tokoh agama bukan untuk menanyakan masalah hukum agama, tetapi justru mengadukan permasalahan kehidupan pribadinya untuk meminta bantuan jalan keluar baik berupa nasehat, saran, meminta doa-doa dan didoakan untuk kesembuhan penyakit maupun keselamatan dan ketenangan jiwa. Hal ini menunjukkan betapa pentingnya pengembangan landasan konseling yang berwawasan agama, terutama dalam rangka menghadapi konseli yang kuat memegang nilai-nilai ajaran agamanya.

\section{PENUTUP}

Usia senja akan datang seiring berjalannya waktu dan merupakan salah satu tahap perkembangan manusia memasuki dewasa akhir atau lanjut usia . Di usia senja seyogianyanya para lanjut usia mampu mencapai integritas kepribadian dalam penerimaan kondisi fisik maupun psikologis yang mulai menurun sehingga mencapai kesehatan yang multidimensional.

Konseling spiritual adalah sebuah upaya pendekatan yang dilakukan Konselor untuk membantu Konseli (Lanjut usia) dalam menemukan makna hidupnya. Proses konseling spiritual didesain berdasarkan spiritualitas pada Lanjut usia yang mengacu pada pelaksanaan konseling pada umumnya. Konselor berupaya membantu Lanjut usia dalam menemukan makna hidup baik untuk dirinya sendiri, bagi orang lain, bagi lingkungan dan makna hidup bagi Tuhan. Melalui Konseling spiritual Lanjut usia dibantu untuk lebih mengenal keberadaan Tuhan sebagai Sang Pencipta dan mengenal dirinya sebagai ciptaanNya. Lanjut usia yang berhasil menemukan makna hidupnya, diharapkan lebih bermanfaat dan bermakna dalam mengisi hidup dipenghujung usianya. Lanjut usia yang memiliki makna hidup tentu akan menyadari keberadaannya sebagai makhluk ciptaan Tuhan yang harus tetap berupaya agar hidupnya lebih bermakna sebelum kembali menghadap Sang Penciptanya.

\section{DAFTAR PUSTAKA}

Bishop, D. Russel, Religious Values as Cross Culture Isues in Counsellin, Journal Counseling and Values, 1992. Vol. 36

Boedi Darmojo, Buku Ajar Geriatri, Jakarta, Fakultas Kedokteran Universitas Indonesia, 1999

Dadang Hawari, Al Qur'an Ilmu Kedokteran Jiwa dan Kesehatan Jiwa, Jakarta, PT. Dana Bhakti Prima Jasa, 1999

Damayanti, Asma, Gambaran Jenis dan Tingkat Kesepian pada Lansia. Bandung:Universitas Padjadjaran . 2008.

Departemen Agama RI, Al Quranul Karim dan Terjemahanya, Semarang: CV. Thoha Putra. 
Hamdani Bakran Adz-Dzaky, Konseling dan Psikoterapi Islam, Yogyakarta: AlManar, 2008. Hasan ,Aliah B Purwakania, Psikologi Perkembangan Islami;Menyikapi Rentang kebidupan Manusia dari Prakelabiran Hingga Pasca Kematian Jakarta:PT Raja Grafindo Persada,2006.

Hesti Widuri, Asuban Keperawatan pada Lanjut Usia ditatanan Klinik, Fitramaya, Yogyakarta, 2010

Hurlock, E. B.. Psikologi Perkembangan : Suatu Pendekatan Sepanjang Rentang Kehidupan. Jakarta : Erlangga, 1992.

Lilik Ma'rifatul Azizah, Keperawatan Lanjut Usia, Graha Ilmu, Yogyakarta, 2011.

Lubis, Lahmudin, Landasan Formal Bimbingan dan Konseling di Indonesia, Bandung, Citapustaka Media Perintis, , 2011

Nugroho, Wahjudi, Keperawatan Gerontik. Jakarta : EGC. 2000

Prof.Dr.H.Prayitno, M.Sc.Ed. dan Drs. Erman Amti; Dasar-Dasar Bimbingan Dan Konseling ; PT Rineka Cipta; Jakarta; 2004: hl.99

R. Siti Maryam, Asuban Keperawatan Lansia,Trans Info Media, Jakarta, 2010. , Mengenal Usia Lanjut dan Perawatannya, Salemba Medika, Jakarta, 2011.

Syamsu Yusuf, L.N, Konseling Spiritual Teistik, Bandung: Rizqi Press, 2009 